\title{
Leaching Fraction: An Effective Tool to Mitigate Ill Effects of Brackish Water
}

\author{
Muhammad Zeeshan Manzoor ${ }^{1 *}$, Ghulam Sarwar ${ }^{1}$, Mukkram Ali Tahir ${ }^{1}$, Noor-Us-Sabah ${ }^{1}$, Ayesha Zafar $^{1}$ \\ and Sher Muhammad ${ }^{2}$
}

${ }^{1}$ Department of Soil and Environmental Sciences, University College of Agriculture, University of Sargodha, Pakistan; ${ }^{2}$ Allama Iqbal Open University, Islamabad, Pakistan.

\begin{abstract}
The general response of plants to soil and water salinity depends upon climate, soil characteristics, topography and management strategies. Water, even may be saline, is becoming more precious natural resource. Hence, there should be more crops and jobs per drop while conserving the quality of present terrestrial and groundwater. Saline water has been used for production of fodder and forages in many countries. Managing soil and water salinity under prevailing conditions of Pakistan is very important subject. Use of brackish water increased the salt concentration of soil. Resultantly, the growth of plants and yield becomes at threat. The salt stress is translated into decrease in growth rate and resultantly, biomass production decreases significantly. This reduction is gradual, depending upon increase in salt concentration in the root medium, while each species has a critical threshold value where it was started showing negative response. Leaching fractions may help keeping salt concentration low in the root zone when irrigation water is saline. In this experiment three types of water (canal, EC = 2 and $3 \mathrm{dS} \mathrm{m}^{-1}$ ) were used as such and with leaching fraction of 10 and $20 \%$. This experiment was conducted in the field and RCBD design was used to make its layout. All the treatments were replicated four times. Sorghum was used as test crop. Pre and post-harvest soil analysis was carried out for different physical and chemical characteristics. Sorghum biomass, plant height, plant diameter and no of plants $/ \mathrm{m}^{2}$ were noted and it was observed from results that leaching fraction technique proved useful to mitigate the ill effects of brackish water. All the collected data were subjected to statistical analysis.

Received | June 11, 2019; Accepted | July 21, 2019; Published | August 15, 2019

*Correspondence | Muhammad Zeeshan Manzoor, Department of Soil and Environmental Sciences, University College of Agriculture, University of Sargodha, Pakistan; Email: zeeshansial106@gmail.com

Citation | Manzoor, M.Z., G. Sarwar, M.A. Tahir, N.U. Sabah, A. Zafar and S. Muhammad. 2019. Leaching fraction: An effective tool to mitigate ill effects of brackish water. Pakistan Journal of Agricultural Research, 32(3): 549-554.

DOI | http://dx.doi.org/10.17582/journal.pjar/2019/32.3.549.554

Keywords | Canal and brackish water, Sorghum, Leaching fractions
\end{abstract}

\section{Introduction}

$\mathrm{W}$ ater is one of the most common and most important substance on earth's surface. Water stress is the key component which has negative effect on crop productivity. In major agricultural countries various techniques are used to save water for increasing a sustainable crop production (Shahid et al., 2012). In low rainfall regions water shortage is taken into consideration as most forbidding factor because of low rainfall. Water shortage is the main problem of arid and semi-arid regions because good quality water is used for other purposes and waste water is used for irrigation purpose (Minhas et al., 2007).

In Pakistan, water shortage is noticeable stress which has adverse impact on the yield of various plants. So improving the wise use of available resources of 
irrigation water is excellent way to enhance the water use efficiency in low rainfall areas (Pawlowski et al., 2009). The shortage of fresh water resource limits the crop production.

Sorghum (Sorghum bicolor L.) is locally recognized as "Jawar" in Pakistan and India and in Africa and China as "durra" and "kaffir corn" (Iqbal, 2015). Sorghum is extensively adopted as fodder and forage crop and has a primary function in cattle farming and has grown extensively throughout the summer time (Amandeep, 2012). Sorghum is suitable for arid to semi-arid regions and accounts for $6 \%$ of total cereal production. The field sorghum production is low@1.4 tons/ha with extensive adaptation (Reddy et al., 2011). In developing countries, economic improvement is based upon processing of domestically grown sorghum to valuable products and beverages. For human intake, more than $35 \%$ of sorghum is grown while, remaining is used in the animal feed industry. (Taylor, 2002). It is the cheapest sources of energy and provides $50 \%$ of micronutrients and vitamins specifically in rural India where people do no longer have easy access to nutrient-wealthy foods (Kumar et al., 2011). It is second cheapest sources of power and micronutrients after millet and the majority of human beings in Africa and India rely on it to fulfill energy requirements and micronutrients (Parthasarathy et al., 2006). It is efficient in water use and is suitably perfect to semi-arid regions, whereas in saline environment it could be the most important economic plants especially when groundwater is a source of irrigation (Rooney and Waniska, 2000). Soil salinity is the main factor that restricts the productivity of agricultural crops, affecting 5-10\% of arable land, approximately 75 to 100 million hectares internationally, in line with estimates (Munns, 2005). In the world, soil salinity and/or sodicity represents extra risk to sustainable agriculture. Keeping in view with a report by $(\mathrm{FAO}, 2000)$ that within the world greater than $8 \times 10^{8}$ ha lands are affected either with sodicity $\left(4.34 \times 10^{8}\right.$ ha $)$ or salinity $\left(3.97 \times 10^{8} \mathrm{ha}\right)$, each of which constitute about $6 \%$ of the total area in the world. Around $56 \%$ of Pakistani soils are saline/sodic (Mirbahar and Sipraw, 2000) and require an external supply of calcium for improvement (Ghafoor et al., 2012). Because of higher ranges of SAR, EC and RSC inside the pumped ground water of Pakistan that negatively affect the crop production and soil properties (Murtaza et al., 2009). While, this water when used appropriately with different management strategies could be helpful in the reclamation of saline soils (Qadir et al., 2001).

It is known that sorghum is relatively extra salt tolerant than different vegetation such as corn or legumes, and has the capacity to be grown as replacement of corn in saline soils (Igartua et al., 1994). Gill et al. (2003) additionally found that at $37^{\circ} \mathrm{C}$ the seeds of sorghum showed reduction in the germination due to salt stress in saline soils. Many researches on sorghum had evaluated its tolerance at the germination stage. But it showed a little tolerance at later stages (Munns et al., 2008). Sorghum is characterized by way of being moderately tolerant to salinity. However, salinity reduces its production and biomass (Almodares and Sharif, 2005). It was known that growth of sorghum was considerably reduced at all salinity stages from 50 to $150 \mathrm{~mm}$. The growth of sorghum is significantly reduced by salinity and this reduction is greater at $250 \mathrm{~mm}$ than at a $125 \mathrm{~mm} \mathrm{NaCl}$ (Ibrahim, 2004). Percentage of germinated seeds is reduced by the burden of salt pressure (Almodares et al., 2007) although at maximum salt concentration the greatest decrease in germination occurred. However, the first choice to increase productivity in soils is by improvement of high yield salinity tolerant sorghum genotypes (Igartua et al., 1994).

\section{Materials and Methods}

This experiment was carried out at College of Agriculture, University of Sargodha sited 32.08 North range and $72.67^{\circ}$ East longitude. Its elevation is above the sea degree is 193 meters.

This study was performed in (RCBD) design with 9 treatments that were replicated four times. The plot size was $3.5 \mathrm{~m} \times 3.5 \mathrm{~m}$ having row to row spacing of 75 $\mathrm{cm}$ and plant to plant distance $25 \mathrm{~cm}$. The treatments of the experiments were as under:

$\mathrm{T}_{1}=$ Irrigation of canal water (control); $\mathrm{T}_{2}=$ Irrigation of water of EC $2.0 \mathrm{dS} \mathrm{m}{ }^{-1} ; \mathrm{T}_{3}=$ Irrigation of water of $\mathrm{EC} 3.0 \mathrm{dS} \mathrm{m}{ }^{-1} ; \mathrm{T}_{4}=$ Irrigation of canal water (control) with 10\% Leaching fraction; $\mathrm{T}_{5}$ $=$ Irrigation of water of EC $2.0 \mathrm{dS} \mathrm{m}^{-1}$ with $10 \%$ Leaching fraction; $\mathrm{T}_{6}=$ Irrigation of water of EC 3.0 $\mathrm{dS} \mathrm{m} \mathrm{m}^{-1}$ with $10 \%$ Leaching fraction; $\mathrm{T}_{7}=$ Irrigation of canal water (Control) with $20 \%$ Leaching fraction; $\mathrm{T}_{8}=$ Irrigation of water of EC $2.0 \mathrm{dS} \mathrm{m}{ }^{-1}$ with $20 \%$ Leaching fraction; $T_{9}=$ Irrigation of water of EC 3.0 $\mathrm{dS} \mathrm{m} \mathrm{m}^{-1}$ with $20 \%$ Leaching fraction. 
Before sowing the sorghum seeds the seed beds were prepared by cultivating the field for 2-3 times with tractor-installed cultivar. Sorghum cultivar "Hegari”was sown@ @ $40 \mathrm{~kg}$ acre $^{-1}$. To keep plant to plant distance $25 \mathrm{~cm}$ thinning was done. The hoeing was done two times in the whole growing season to reduce weed-crop competition. The first irrigation was applied after 10 days of germination while other irrigations were applied to the crop according to water requirements of the crops. Fertilizers like SOP, SSP and Urea were the N, P, K sources used in the experiment. At maturity the crop was harvested and different parameters were noted. Sorghum biomass, plant height, plant diameter and no of plants $/ \mathrm{m}^{2}$ were noted. Before sowing and after harvesting the crop, soil analysis was carried out. The soil sample were collected from the depth of $0-15 \mathrm{~cm}$ with the help of soil auger. From every plot soil sample was collected. The analysis was made according to the methods written in Hand Book 60 of U.S Laboratory Staff (1954). Soil samples dried in oven were used for all determinations. Physio-chemical properties of soil before cultivation were as indicated here:

$\begin{array}{lll}\text { Parameters } & \text { Unit } & \text { Value } \\ \mathrm{pH}_{\mathrm{s}} & - & 8.1 \\ \mathrm{EC}_{\mathrm{e}} & \mathrm{dSm}^{-1} & 0.89 \\ \mathrm{SAR} & - & 3.62 \\ \text { Soil textural class } & - & \text { Clay loam }\end{array}$

\section{Results and Discussion}

\section{Plant height $(\mathrm{cm})$}

The height of plants is an important feature of the plants on which the strength and growth of the plant depends. The height of the plant is directly proportional to the growth rate. The maximum height of the sorghum plants was obtained from the plots which were under the canal water irrigation followed by the plots irrigated with the water of EC $2.0 \mathrm{dS} \mathrm{m} \mathrm{m}^{-1}$ and EC $3.0 \mathrm{dS} \mathrm{m}^{-1}$. Similar effect of leaching fraction was observed within treatments and sub treatments. Plant height of the plots having 20\% leaching fraction was noted to be higher than those having 10 and $0 \%$ leaching fraction. The treatment $\mathrm{T}_{7}$ demonstrated dominance over all the other treatments because of canal water with $20 \%$ leaching fraction. As the EC of irrigation water increased and the leaching fraction decreased plant height was reduced. The minimum plant height was observed in the plots of treatment $\mathrm{T}_{3}$ which were irrigated with the water of EC $3.0 \mathrm{dSm}^{-1}$ with $0 \%$ leaching fraction followed by $\mathrm{T}_{6}$ (water of EC $3.0 \mathrm{dS} \mathrm{m}^{-1}$ with $10 \%$ leaching fraction) and $\mathrm{T}_{9}$ (water of EC $3.0 \mathrm{dS} \mathrm{m}^{-1}$ with $20 \%$ leaching fraction) respectively (Figure 1 ). The treatments, $T_{6}$ and $T_{9}$ were statistically similar with each other in term of sorghum plant height. These results are supported by Noaman and El-Haddad (2000) who reported that plant height of crop plant improved significantly by increasing leaching fraction from 0.25 to $0.50 \%$ under irrigation with saline water. According to Glenn et al. (1991) high leaching fraction under irrigation with seawater increase the plant height of crop.

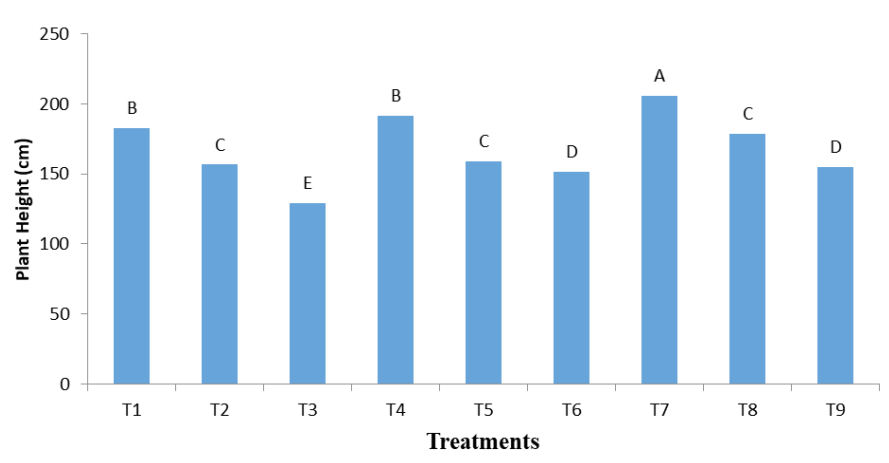

Figure 1: Impact of canal and saline water with and without leaching fraction on plant height (cm) of sorghum.

\section{Stem diameter $\left(\mathrm{cm}^{2}\right)$}

Stem diameter indicates the girth of the plant stem. Generally, it determines the growth and vigor of the crop plant. Stem diameter shows substantial response to saline water. Data about stem diameter is presented in Figure 2 which indicated that saline water impart significant effect on stem diameter of sorghum. The highest stem diameter of the sorghum plants was obtained from the plots which were under the canal water irrigation followed by the pots irrigated with the water of EC $2.0 \mathrm{dS} \mathrm{m} \mathrm{m}^{-1}$ and EC $3.0 \mathrm{dS} \mathrm{m}$. Similar effect of leaching fraction was observed within treatments and sub treatments. Stem diameter of the plots having 20\% leaching fraction was noted to be higher than those having 10 and $0 \%$ leaching fraction. The treatment $\mathrm{T}_{7}$ demonstrated dominance over all the other treatments because of canal water with $20 \%$ leaching fraction. As the EC of irrigation water increased and the leaching fraction decreased stem diameter was reduced. The minimum stem diameter was observed in the plots of treatment $\mathrm{T}_{3}$ which were irrigated with the water of EC $3.0 \mathrm{dSm}^{-1}$ with $0 \%$ leaching fraction followed by $\mathrm{T}_{6}$ (water of EC $3.0 \mathrm{dS}$ $\mathrm{m}^{-1}$ with $10 \%$ leaching fraction) and $\mathrm{T}_{9}$ (water of $\mathrm{EC}$ $3.0 \mathrm{dS} \mathrm{m}^{-1}$ with $20 \%$ leaching fraction) respectively 
(Figure 2). The treatments, $\mathrm{T}_{6}$ and $\mathrm{T}_{9}$ were statistically similar with each other in term of sorghum stem diameter. These results are similar to the findings of Almodares et al. (2007) who reported that growth and stem diameter of sorghum decreases under irrigation with saline water. The work of Noaman and El-Haddad (2000) showed that irrigation with saline water under high leaching fraction reduced the negative impact of salinity on growth traits of halophytes species.

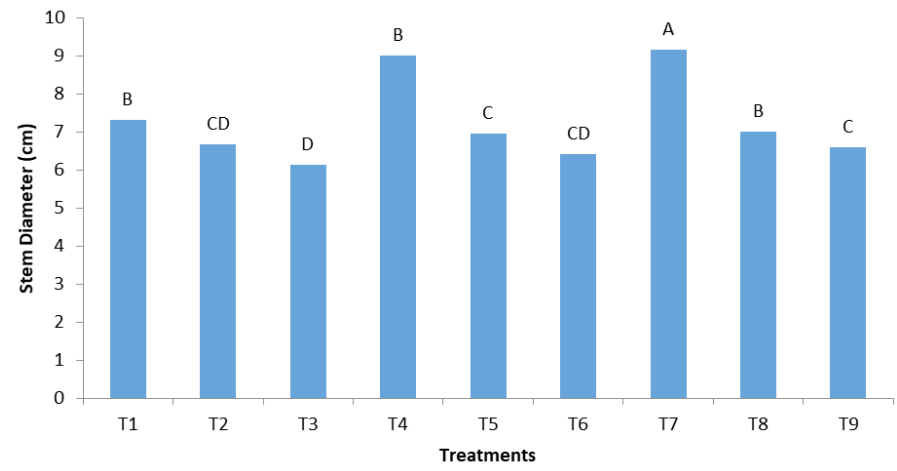

Figure 2: Impact of canal and saline water with and without leaching fraction on stem diameter $\left(\mathrm{cm}^{2}\right)$ of sorghum.

\section{Number of plants $/ \mathrm{m}^{2}$}

Number of plants $/ \mathrm{m}^{2}$ is one of the most essential characters in term of cropyield. To obtain the maximum crop growth and yield optimum plant population is essential. The data indicated that irrigation with saline water had no impact on number of plants $/ \mathrm{m}^{2}$. However, the maximum number of plants $/ \mathrm{m}^{2}$ (29) of sorghum was recorded in the treatment grown under canal water with $10 \%$ of leaching fraction $\left(\mathrm{T}_{4}\right)$. The treatments, $\mathrm{T}_{1}$ (canal water with $0 \%$ leaching fraction), $\mathrm{T}_{7}$ (canal water with $20 \%$ leaching fraction) and $\mathrm{T}_{8}$ (water of EC $2.0 \mathrm{dS} \mathrm{m} \mathrm{m}^{-1}$ with $20 \%$ leaching fraction) produced 27 plants $/ \mathrm{m}^{2}$ (Figure 3). Similarly, the 26 number of plants $/ \mathrm{m}^{2}$ produce by $\mathrm{T}_{2}$ (water of EC $2.0 \mathrm{dS} \mathrm{m}^{-1}$ with $0 \%$ leaching fraction), $\mathrm{T}_{5}$ (water of EC $2.0 \mathrm{dsm}^{-1}$ with $10 \%$ leaching fraction) and $\mathrm{T}_{9}$ (water of EC $3.0 \mathrm{dSm}^{-1}$ with $20 \%$ leaching fraction). The minimum number of plants $/ \mathrm{m}^{2}$ (25) of sorghum was recorded where irrigation was applied with water of EC $3.0 \mathrm{dSm}^{-1}$ with $0 \%$ leaching fraction $\left(\mathrm{T}_{3}\right)$. According to Almodares et al. (2007) salinity has little effect on seed germination but they cannot grow continuously under high level of salinity. Jamil et al. (2005) also applied different levels of salt stress (0.0, 4.7, 9.4 and $14.1 \mathrm{dS} \mathrm{m}^{-1}$ ) on cauliflower, canola and cabbage. They revealed that germination \% in all three species decreased significantly with increasing salinity up to $14.1 \mathrm{dS} \mathrm{m}^{-1}$.

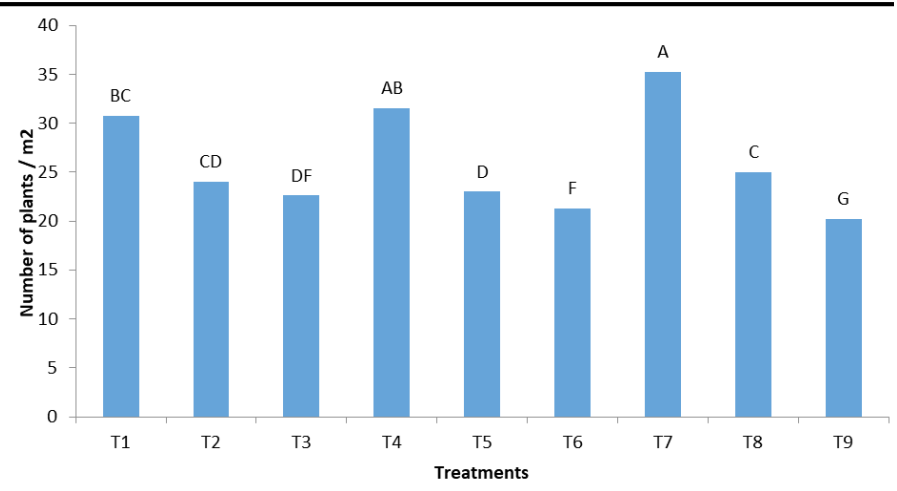

Figure 3: Impact of canal and saline water with and without leaching fraction on number of plants $/ m^{2}$ of sorghum.

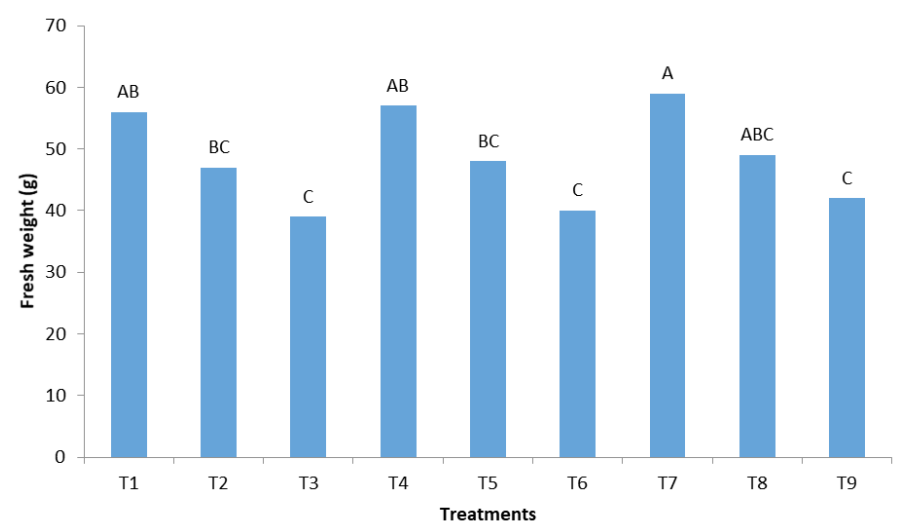

Figure 4: Impact of canal and saline water with and without leaching fraction on fresh weight/biomass $\left(t \mathrm{ha}^{-1}\right)$ of sorghum.

\section{Fresh weight $\left(t h a^{-1}\right)$}

Fresh weight of plant determines the biological yield of sorghum. More the fresh weight more will be the total green fodder yield that improved the crop productivity under salt stress. Data showed that use of saline water affected fresh weight of sorghum significantly. Among all the treatments, fresh weight of the sorghum plants was obtained from the plots which were under the canal water irrigation followed by the plots irrigated with the water of EC $2.0 \mathrm{dS} \mathrm{m}^{-1}$ and EC $3.0 \mathrm{dS} \mathrm{m}^{-1}$. Similar effect of leaching fraction was observed within treatments. Fresh weight of the plots having 20\% leaching fraction was noted to be higher than those having 10 and $0 \%$ leaching fraction. The treatment $T_{7}$ demonstrated dominance over all the other treatments because of canal water with 20\% leaching fraction. As the EC of irrigation water increased and the leaching fraction decreased fresh weight was reduced. The minimum fresh weight was observed in the plots of treatment $\mathrm{T}_{3}$ which were irrigated with the water of EC $3.0 \mathrm{dS} \mathrm{m} \mathrm{m}^{-1}$ with $0 \%$ leaching fraction followed by $\mathrm{T}_{6}$ (water of EC $3.0 \mathrm{dS}$ $\mathrm{m}^{-1}+10 \%$ leaching fraction) and $\mathrm{T}_{9}$ (water of EC 3.0 $\mathrm{dS} \mathrm{m} \mathrm{m}^{-1}+20 \%$ leaching fraction) respectively (Figure 4). The treatments, $T_{6}$ and $T_{9}$ were statistically similar 
with each other in term of sorghum fresh weight. These results are supported by the findings of Gill et al. (2003) who indicated that irrigation with saline water cause reduction in the fresh weight of sorghum by increasing salinity levels. According to Glenn and O'Leary (1985) higher fresh weight were obtained from halophytes species under daily irrigation of seawater at high leaching fraction.

\section{Conclusions and Recommendations}

The results of the experiment revealed that management technique of leaching fraction proved effective in reducing the detrimental effects of saline water. The results of the study demonstrated that application of saline water with leaching fraction at various rates mitigated the deleterious effects of saline water on the growth of sorghum by improving the properties of soil. Among all the treatments, $T_{7}$ (canal water $+20 \%$ leaching fraction) performed the best which produced the highest values of growth parameters like sorghum biomass, plant height, plant diameter and no of plants $/ \mathrm{m}^{2}$.

\section{Author's Contribution}

Muhammad Zeeshan Manzoor: Researcher/Scholar Ghulam Sarwar: Academic Surpervisor and guided throughout the research tenure.

Mukkram Ali Tahir and Noor-Us-Sabah: Member of supervisory committee and contributed in all research work.

Ayesha Zafar: Member of research group and helped in laboratory analysis.

Sher Muhammad: Contributed in paper write up and statistical analysis.

\section{References}

Almodares, A. and M.E. Sharif. 2005. Effect of water quality on yield of sugar beet and sweet sorghum. J. Environ. Biol. 26: 487-493.

Almodares, A. and M.E. Sharif. 2007. Effects of irrigation water qualities on biomass and sugar contents of sugar beet and sweet sorghum cultivars. J. Environ. Biol. 28: 213-218.

Amandeep, S. 2012. Forage quality of sorghum (Sorghum bicolor) as influenced by irrigation, nitrogen levels and harvesting stage. India. J. Sci. Res. 3(2): 67-72.

FAO. 2000. Extent and causes of salt-affected soils in participating countries. Land and plant nutrition management service. FAO Soils Bull. No. 77, FAO, Rome, Italy.

Ghafoor, A., G. Murtaza, M.Z. Rehman, Saifullah and M. Sabir. 2012. Reclamation and salt leaching efficiency of treatments for tile drained saline-sodic soil using marginal quality water for irrigating rice and wheat crops. Land Degr. Dev. 23: 1-9. https://doi.org/10.1002/ldr.1033

Gill, P.K., A.D. Sharma, P. Singh and S.S. Bhallar. 2003. Osmotic stress-induced changes in germination, growth and soluble sugar content of Sorghum bicolor (L.) seeds. Bulg. J. Plant Physiol. 28: 12-25.

Glenn, E. and J. O'leary. 1985. Productivity and irrigation requirements of halophytes grown with seawater in the Sonora Desert. J. Arid Environ. 9: 81-91. https://doi.org/10.1016/ S0140-1963(18)31273-4

Glenn, E.P., J.W. O'LEARY, M.C. Watson, T.L. Thompson and R.O. Kuehl. 1991. Salicornia bigelovii Torr: an oilseed halophyte for seawater irrigation. Sci., 251(4997): 1065-1067. https:// doi.org/10.1126/science.251.4997.1065

Ibrahim, A.H. 2004. Efficacy of exogenous glycine betaine application on sorghum plants grown under salinity stress. Acta Bot. Hung. 43(3-4): 307-318. https://doi.org/10.1556/ ABot.46.2004.3-4.5

Igartua, E., M.P. Garcia and J.M. Lasa. 1994. Field responses of grain sorghum to a salinity gradient. Field Crops Res. 42: 15-25. https:// doi.org/10.1016/0378-4290(95)00018-L

Iqbal, M.A. 2015. Overviewing forage shortage for dairy animals and suitability of forage sorghum for ensiling. Glob. Vet. 14(2): 173-177.

Jamil, M., C.L. Cheong, U.R. Shafiq, B.L. Deok and A. Muhammad. 2005. Salinity $(\mathrm{NaCl})$ tolerance of brassica species at germination and early seedling growth. J. Agric. Food Chem. 4: 970-976.

Kumar, A.A., B.V.S. Reddy, H.C. Sharma, C.T. Hash, P.S. Rao, B. Ramaiah and P.S. Reddy. 2011. Recent advances in sorghum genetic enhancement research at ICRISAT. Am. J. Plant Sci. 2: 589-600. https://doi.org/10.4236/ ajps.2011.24070

Minhas, P.S., S.K. Dubey and D.R. Sharma. 2007. Comparative effects of blending, intera/interseasonal cyclic uses of alkali and good quality waters on soil properties and yields of paddy 
and wheat. Agric. Water Manage. 87: 83-90. https://doi.org/10.1016/j.agwat.2006.06.003

Mirbahar, M.B. and A.M. Sipraw. 2000. On-Farm tile drainage with farmers participant, past experience and future strategies. Proceeding National Seminar on Drainage in Pakistan, August 16-18,2000 held at MUET,Jamshoro, pp. 1-14.

Munns, R. and M. Tester. 2008. Mechanisms of salinity tolerance. Ann. Rev. Plant Biol. 59: 651-681. https://doi.org/10.1146/annurev. arplant.59.032607.092911

Munns, R. 2005. Genes and salt tolerance: bringing them together. New Phytol. 167: 645-663. https://doi.org/10.1111/j.14698137.2005.01487.x

Murtaza, G., A. Ghafoor, G. Owens, M. Qadir and U.Z. Kahlon. 2009. Environmental and economic benefits of saline-sodic soil reclamation using low-quality water and soil amendments in conjuction with a rice-wheat cropping system. J. Agron. Crop Sci. 195: 124-136. https://doi.org/10.1111/j.1439037X.2008.00350.x

Noaman, M.N. and E. EL-Haddad. 2000. Effects of irrigation water salinity andleaching fraction on the growth of six halophyte species. J. Agric. Sci. Camb. 135: 279-285. https://doi. org/10.1017/S0021859699008333

Parthasarathy, R.P., B.S. Birthal, B.V.S. Reddy, K.N. Rai and S. Ramesh. 2006. Diagnostics of sorghum and pearl millet grains-based nutrition in India. Int. Sorghum Mill. Newsl. 47: 93-96.

Pawlowski, A., J.L. Guzman, F. Rodriguez, M.
Berenguel, J. Sanchez and S. Dormido. 2009. Simulation of greenhouse climate monitoring and control with wireless sensor network and event-based control. J. Sensors. 9: 232-252. https://doi.org/10.3390/s90100232

Qadir, M., A. Ghafoor and G. Murtaza. 2001. Use of saline-sodic water through phytoremediation of calcareous saline-sodic soils. Agric. Water Manage. 50: 197-210. https://doi.org/10.1016/ S0378-3774(01)00101-9

Reddy, B.V.S., A.A. Kumar, S. Ramesh and P.S. Reddy. 2011. Breeding sorghum for coping with climate change. Crop Adaptation Clim. Change, Wiley, Iowa, USA.

Rooney, W.L. and C.W. Smith. 2000. Chapter 2.4: Techniques for developing new cultivars. In: Sorghum: Origin, history, technology and production, Smith, C.W., Frederiksen R.A., eds. John Wiley and Sons New York. 329-347.

Shahid, M.A., M.A. Pervez, R.M. Balal, N.S. Mattson, A. Rashid, R. Ahmad, C.M. Ayyub and T. Abbas. 2011. Brassinosteroid (24-epibrassinolide) enhances growth and alleviates the deleterious effects induced by salt stress in pea (Pisum sativum L.). Aust.J. Crop Sci. 5(5): 500-510.

Taylor, J.R.N. and P. S . Belton.2002. Distribution of selenium in different biochemical fractions and raw darkening degree of potato (Solanum tuberosum L.) tubers supplemented with selenite. J. Agric. Food Chem. 54: 86178622. https://doi.org/10.1021/jf0613987

U.S. Salinity Laboratory Staff. 1954. Diagnosis and Improvements of saline and alkali soils. Handbook No. 60. USDA. U.S. Govt. Printing Office, Washington, DC, USA. 